\title{
Dynamic Patterns in Vietnam's Comparative Advantage
}

\author{
Nguyen K. Doanh*, Yoon Heo**
}

\begin{abstract}
This paper investigates the dynamic patterns of Vietnam's comparative advantage in the context of ASEAN. Using the Galtonian regression method and the Markov transition probability matrices for data from 1997 to 2008, we find the following: Firstly, commodity groups with a weak comparative advantage improved their competitiveness, whereas those groups with a strong comparative advantage saw it decline, indicating a convergence of their comparative advantages. Secondly, in terms of intra-distribution dynamics, industries with no initial comparative advantage (Class a) and those with a strong initial comparative advantage (Class d) showed a high degree of persistence, suggesting a low degree of mobility in the trade patterns for Classes $a$ and $d$. Thirdly, mineral resource-intensive products showed a high degree of export specialization, whereas other product categories showed a high degree of export diversification. Fourthly, all commodity groups showed a downward trend in the degree of specialization. Finally, Vietnam's exports were dominated by unskilled labor-intensive products and agricultural resource-intensive products, reflecting the validity of Heckscher-Ohlin model. As a result of the country's trade liberalization, the patterns of Vietnam's comparative advantage have come to reflect its factor endowment. These results suggest that Vietnam could better diversify its export structures and shift to exports based on human capital and technology by further liberalizing its trade policies, fostering human capital formation, and facilitating the transfer of technology.
\end{abstract}

Keywords: revealed comparative advantage, Galtonian regression, transition probability matrix, Gini-Hirschman index, Vietnam, ASEAN

Submission Date: 4/25/2011 Revision Date: 06/07/2011 Acceptance Date: 06/07/2011

* Dean, Faculty of Graduate Studies, Thai Nguyen University of Economics and Business Administration, Vietnam. Email: nkdoanh@yahoo.com, Tel.84-977-242268Fax:84-2803-647684.

** Corresponding author, Professor, Graduate School of International Studies, Sogang University, Korea. Email:hury@sogang.ac.kr Tel.82-2-705-8948 Fax:82-2-705-8755. 


\section{Introduction}

Trade liberalization in Vietnam over the last two decades has been regarded as one of the most important pillars of its reform package. Its economic reform process (DoiMoi), which began in 1986 and has deepened since 1995, represents a number of major changes through which Vietnam has reshaped its international trade regime. After an initially hesitant start in the late 1980s, its liberalization efforts have accelerated since 1995, when Vietnam acceded to joining the Association of Southeast Asian Nations (ASEAN). Accordingly, a series of important steps had to been taken to ensure various economic and liberalization reforms, putting the country on a path to become a more open, marketoriented economy.

For Vietnam, the potential benefits have included increased trade, greater economies of scale in production, and better access to resources for production. Another major gain has involved improved efficiency as a result of increased competition and enhanced access to foreign technology. Through this phenomenon, liberalized trade between Vietnam and its trading partners has created potential opportunities for Vietnam to pursue production and export specialization based on its comparative advantage. Thus, there is a current need to identify the commodity groups in which Vietnam enjoys comparative advantages and to analyze the dynamics of Vietnam's current trade patterns.

This paper provides an empirical analysis of the patterns and dynamics of Vietnam's comparative advantages in the context of ASEAN. The concept of comparative advantage was developed to explain the underlying reasons for international trade and to help predict the trade pattern resulting from changes in a country's ever improving factor endowment and technology. Accordingly, free trade allows countries to benefit by specializing in areas in which they have comparative advantages under autarky. This study's empirical analysis is based on the revealed comparative advantage (RCA) index through the period of 1997-2008. Because the topic of special interest here is Vietnam's comparative advantages in the context of ASEAN, this study calculates its RCA's by comparing them with those of the other members of ASEAN. In this regard, this study focuses on the following research objectives:

- To assess the patterns and dynamics of Vietnam's comparative advantages in the context of ASEAN.

- To analyze the mobility of Vietnam's revealed comparative advantages and the degree of its export specialization.

- To derive policy implications based on empirical findings. 
The rest of this paper is structured as follows. Section 2 provides the indicators and the background for the analysis of Vietnam's comparative advantage. Section 3 describes the data. Section 4 presents an in-depth analysis of the patterns and dynamics of Vietnam's comparative advantages, and Section 5 discusses important policy implications and gives a conclusion based on our findings.

\section{Methodology}

\subsection{Revealed Comparative Advantage and Its Modifications}

Previous studies have measured a country's relative export performance by employing the RCA index ${ }^{1)}$. The advantage of using the RCA index is that it considers the intrinsic advantage of a particular export commodity and is consistent with changes in an economy's relative factor endowment and productivity. The RCA index, however, also has some limitations, including its asymmetric property. The index has a fixed lower bound of zero and a variable upper bound.

Although the strengths and weaknesses of the RCA concept continue to be a subject of much debate, it remains the most widely used comparative index (Grigorovici, 2009). Previous studies have suggested several modifications to address the perceived problems found in the original RCA index. ${ }^{2}$ ) The first improvement was proposed by Vollrath (1991), who modified the index by taking natural logarithms and using $\ln R C A_{i j}$ in the regression equation. The second improvement was suggested by Laursen (1998), who normalized the RCA index by using revealed symmetric comparative advantage: $R S C A_{i j}=\left(R C A_{i j}-1\right)$ $/\left(R C A_{i j}+1\right)$. The resulting index ranges from -1 to +1 . Finally, Proudman and Redding (2000) and Amador et al. (2007). proposed an alternative measure of RCA in which acountry's export share in a given product group is divided by its mean export share in all commodity groups: $R C A_{i j} /\left(1 / n\left(\sum_{i} R C A_{i j}\right)\right.$.

Hillman (1980) developed a necessary and sufficient condition for a correspondence between the RCA index and pre-trade relative prices for cross-country comparisons involving a given product:

\footnotetext{
1) See Appendix 1 for the measurement of the RCA index.

2) Our empirical analysis is consistent with these extensions
} 


$$
1-\frac{X_{i j}}{X_{i n}}>\frac{X_{i j}}{X_{j}}\left(1-\frac{X_{j}}{X_{n}}\right)
$$

where $X_{i j}$ indicates exports of commodity $i$ by country $j ; X_{j}$ indicates total exports by country $j ; X_{i n}$ is the reference group's exports of commodity $I$; and $X_{n}$ is the reference group's amount of total exports. Given identical homothetic preferences across countries, the above equation provides a condition that is necessary and sufficient for guaranteeing that changes in the RCA index are consistent with the changes in relative factor endowments. This condition guarantees that growth in the level of a country's exports in a commodity result in an increase on the RCA index.

\subsection{Structural Stability}

\subsubsection{Stability of the RCA Distribution}

The persistence of the overall specialization pattern is captured by the Galtonian regression method (Laursen, 1998; Bojnec \& Ferto, 2008), which traces the correlation between the RCA index in period $t$ and the index in subsequent periods. Following Dalum et al. (1998). we perform the following regression analysis:

$$
R C A_{i j}^{t 2}=\alpha_{i}+\beta_{i} R C A_{i j}^{t 1}+u_{i j}
$$

where the superscripts $t_{1}$ and $t_{2}$ denote the starting year and the ending year, respectively; the dependent variable RCA at time $t_{2}$ for sector $i$ in country $j$ is tested against the independent variable, which is the value of RCA in year $t_{1} ; \alpha$ and $\beta$ are standard linear regression parameters; and $u_{i j}$ is a residual term. Estimated coefficients allow for the determination of whether there is a change in the structure of trade specialization between periods.

- If $\beta=1$ : The specialization pattern does not change from $t_{1}$ to $t_{2}$.

- If $\beta>1$ : The country's existing specialization increases for those commodity groups in which the country has a comparative advantage and decreases for those in which it does not. 
- If $0<\beta<1$ : The commodity groups in which the country has a weak comparative advantage become more competitive, whereas those in which the country has a strong comparative advantage become less competitive. This implies a convergence of export specialization.

- If $\beta<0$ : There is a complete change in the structure of the comparative advantage.

According to Cantwell (1989) and Dalum et al. (1998), $\beta>1$ is not a necessary condition for an increase in the overall specialization pattern. It can be shown that

$$
\sigma_{i}^{2 t 2} / \sigma_{i}^{2 t 1} /=\beta_{i}^{2} / R_{i}^{2} \text { thus, } \sigma_{i}^{t 2} / \sigma_{i}^{t 1}=\left|\beta_{i}\right| /\left|R_{i}\right|
$$

where $\sigma_{i}^{2}$ is the variance of the dependent variable and $R$ is the correlation coefficient obtained from the regression. If $\beta_{i}=R_{i}$, then there is no change in the dispersion of a given distribution; if $\beta_{i}>R_{i}$, then there is an increase in the degree of specialization ( $\sigma$ specialization); and if $\beta_{i}<R_{i}$, then the degree of specialization declines ( $\sigma$-despecialization).

\subsubsection{The Intra-Distribution Dynamics}

There are several measures of the stability of the values of the RCA index for particular commodity groups from $t_{1}$ to $t_{2}$. Following Proudman and Redding (2000), Brasili et al. (2000), Hinloopen and van Marrewijk (2001), and Bojnec and Ferto (2008), we will employ Markov transition probability matrices to assess the mobility of the RCA (measured by the RCA index). There has thus far been no consensus on the classification of the RCA index into appropriate categories. Thus, following Hinloopen and van Marrewijk (2001), we will classify the RCA index into the following four categories:

- $0<\mathrm{RCA} \leq 1$ : Products with no comparative advantage.

- $1<\mathrm{RCA} \leq 2$ : Products with a weak comparative advantage.

- $2<\mathrm{RCA} \leq 4$ : Products with a moderate comparative advantage.

- 4 <CA: Products with a strong comparative advantage. 
In general, a stochastic process of $X$ is considered to be Markovian if for every $n$ and all states $i_{1}, \ldots i_{n}$,

$$
P\left[X_{n}=i_{n} \mid X_{n-1}=i_{n-1}, \ldots, X_{1}=i_{1}\right]=P\left[X_{n}=i_{n} \mid X_{n-1}=i_{n-1}\right]
$$

Our transition matrices are used in the Markovian analysis. As a result, the relative frequency should be interpreted as the probability. In this paper, the transition matrices are generated by the stationary Markov process

$$
P\left[X_{n}=j \mid X_{n-1}=i\right]=P\left[X_{n+k=j} \mid X_{n+k-1}\right]
$$

for all states $i$ and $j, \mathrm{k}=(\mathrm{n}-1), \cdots, 1,0,1, \cdots$

The degree of mobility found in the patterns of specialization can be analyzed through several other indices. The first index is $M_{1}$, which evaluates the trace(tr) of the transition probability matrix (Shorrocks, 1978; Quah, 1996). Here $M_{1}$ is calculated as follows:

$$
M 1=\frac{K-\operatorname{tr}\left(P_{c}^{*}\right)}{K-1},
$$

where $\mathrm{K}$ is the number of cells and $\operatorname{tr}\left(P_{c}^{*}\right)$ is the trace of the transition probability matrix. A higher value on the index indicates greater mobility, whereas a value of zero indicates perfect immobility.

The second index of mobility is $M_{D}\left(P^{*}\right)$, which evaluates the determinant of the transition probability matrix. Here $M_{2}$ is computed as follows:

$$
M_{2}=1-\left|\operatorname{det}\left(P^{*}\right)\right|
$$

where $\operatorname{det}\left(P^{*}\right)$ is a determinant of the matrix calculated as $|B|=\sum_{j=1}^{4} b_{1 j}\left|C_{1 j}\right|$ In this paper, the cofactors $\left|C_{1 j}\right|$ are of order 3 . 


\subsection{Degree of Commodity Concentration}

In this study, commodity concentration is estimated based on the Gini-Hirschman coefficient $(\mathrm{GH})$. The index is calculated as follows:

$$
G H=\sqrt{\sum_{i=1}^{n}\left(\frac{X_{i t}}{X_{t}}\right)^{2}},
$$

where $X_{i t}$ is the value of the exports in commodity group $i$ in year $t$ and $X_{t}$ indicates the total exports in year $t$. The GH coefficient ranges from 0 (export diversification) to 1 (export specialization).

\section{Data}

The data for this research was drawn from the United Nations Commodity Trade Statistics. The annual RCA index was calculated using the Standard International Trade Classification (SITC) at the three-digit industry level, but is reported using either the SITC at the three-digit industry level or product groups by factor intensity for the period 1997-20083). We used this RCA index to determine any differences in the trade structure between Vietnam and ASEAN. Further, this index provides useful information on prospects for potential trade with prospective trading partners.

\section{Empirical Results}

\subsection{Overview of the Pattern of Vietnam'sExports}

Table 1 shows Vietnam's export structure based on factor intensity4). Vietnam's exports were dominated by unskilled labor - and agricultural resource-intensive products. Such products accounted for approximately 33\% and 32\% of total exports in 1997 and 1999, respectively. Mineral resource - intensive products accounted for the third largest

\footnotetext{
3) We follow Krause (1982) for the classification of commodities.

4) Appendix 2 presents the share of each commodity in Vietnam's total exports for each year.
} 
portion of exports, followed by technology - intensive products and human capital - intensive products, respectively.

Table 1.

Commodity shares in Vietnam's total exports

\begin{tabular}{l|c|c|c|c}
\hline \multicolumn{1}{c|}{ Product groups } & $\mathbf{1 9 9 7 - 1 9 9 9}$ & $\mathbf{2 0 0 0 - 2 0 0 2}$ & $\mathbf{2 0 0 3 - 2 0 0 5}$ & $\mathbf{2 0 0 6 - 2 0 0 8}$ \\
\hline \hline Agricultural resource-intensive products & 31.93 & 27.91 & 23.76 & 23.30 \\
\hline Mineral resource-intensive products & 19.38 & 24.83 & 25.14 & 22.96 \\
\hline Unskilled labor-intensive products & 32.87 & 32.89 & 35.99 & 34.50 \\
\hline Human capital-intensive products & 2.75 & 3.73 & 5.02 & 6.85 \\
\hline Technology-intensive products & 7.97 & 8.22 & 9.28 & 11.10 \\
\hline Three-digit sectors not classified & 5.10 & 2.41 & 0.81 & 1.29 \\
\hline
\end{tabular}

Source: The authors' own computation.

The most discernable change is the reduction in the traditional dominance of exports in the agricultural sector between the periods 1997-1999 and 2006-2008. At the same time, the share of mineral resource-intensive products in total exports, the third largest commodity group, fluctuated during the same period. By contrast, the percentage of unskilled labor-intensive products in total exports rose. Another interesting feature about Vietnam's exports is the consistent increase in the share of human capital- and technology-intensive commodities in total exports. Although still very low, this increase indicates a movement toward a knowledge- and technology-based economy. Taken together, the patterns of Vietnam's exports reflect its factor endowment.

\subsection{Vietnam's RCA Pattern in the context of ASEAN}

Table 2 summarizes the RCA estimates for 249 products at the three-digit SITC level.5) For the purpose of mitigating any random factors, which might influence a single year RCA estimate, we are reporting on three-year averages (1997-1999, 2000-2002, 2003-2005, and 2006-2008). $\left.{ }^{6}\right)$

5) The frequency distribution of Vietnam's RCA by factor intensity is reported in Appendix 3.

6) Our RCA estimates are consistent with the Hillman condition. Detailed information is available from the authors upon request. 
Table 2.

Frequency Distribution of Vietnam's RCA index

\begin{tabular}{c|c|c|c|c}
\hline RCA range & $\mathbf{1 9 9 7 - 1 9 9 9}$ & $\mathbf{2 0 0 0 - 2 0 0 2}$ & $\mathbf{2 0 0 3 - 2 0 0 5}$ & $\mathbf{2 0 0 6 - 2 0 0 8}$ \\
\hline \hline $0<\mathrm{RCA} \leq 1$ & 188 & 175 & 161 & 151 \\
\hline $1<\mathrm{RCA} \leq 2$ & 20 & 32 & 37 & 40 \\
\hline $2<\mathrm{RCA} \leq 4$ & 16 & 14 & 27 & 26 \\
\hline $4<\mathrm{RCA}$ & 25 & 28 & 24 & 32 \\
\hline Total & 249 & 249 & 249 & 249 \\
\hline Mean RCA & 1.38 & 1.45 & 1.36 & 1.60 \\
\hline Maximum & 33.26 & 19.92 & 11.82 & 14.15 \\
\hline Standard deviation & 3.31 & 2.29 & 2.21 & 2.42 \\
\hline
\end{tabular}

Source: The authors' computation using data from the UNSD.

According to Table 2, more than 50\% of the product categories had an RCA value of less than or equal to the unity for 1997-2008. However, the number of such product categories gradually declined over time. During the same period, the number of product categories with a weak, moderate, or high comparative advantage increased. At the same time, the mean RCA value at the aggregate level rose slightly, indicating improvement in the commodity structure of Vietnam's comparative advantage. Table 3 shows the percentage of products with an RCA value greater than the unity for each product category.

\section{Table 3.}

Percentage of Products with an RCA Value Greater than the Unity at the Three-Digit SITC Level

\begin{tabular}{l|c|c|c|c}
\hline \multicolumn{1}{c|}{ Product Categories } & $\mathbf{1 9 9 7 - 1 9 9 9}$ & $\mathbf{2 0 0 0 - 2 0 0 2}$ & $\mathbf{2 0 0 3 - 2 0 0 5}$ & $\mathbf{2 0 0 6 - 2 0 0 8}$ \\
\hline \hline Total & $\mathbf{2 4 . 5 0}$ & $\mathbf{2 9 . 7 1}$ & $\mathbf{3 5 . 3 4}$ & $\mathbf{3 9 . 3 5}$ \\
\hline Agricultural resource-intensive products & 45.46 & 48.48 & 56.06 & 54.55 \\
\hline Mineral resource-intensive products & 24.33 & 24.32 & 24.33 & 35.13 \\
\hline Unskilled labor-intensive products & 41.66 & 61.11 & 63.90 & 75.00 \\
\hline Human capital-intensive products & 6.98 & 16.28 & 20.94 & 25.58 \\
\hline Technology-intensive products & 5.97 & 7.46 & 11.95 & 16.42 \\
\hline
\end{tabular}

Source: The authors' computation using data from the UNSD. 
As shown in Table 3, the percentage of products with a comparative advantage dramatically rose from $24.5 \%$ in $1997-1999$ to $39.5 \%$ in $2006-2008$. This means that a large number of products acquired a comparative advantage during these periods. Unskilled labor-intensive products were the most successful (an increase of approximately 34 percentage points), followed by human capital-intensive products (approximately 20 percentage points). Agricultural resource-intensive products, mineral resource-intensive products, and technology-intensive products showed an increase of approximately 10 percentage points.

Table 4 shows the factor intensity pattern of Vietnam's RCA. Vietnam had a comparative advantage in agricultural resources-, mineral resources-, and unskilled labor-intensive products in all four periods. This phenomenon is consistent with the principle of comparative advantage under which a country should specialize in the production of and export the products that make intensive use of its relatively abundant factors. Thus, as an economy based on abundant labor and agriculture, Vietnam is expected to have comparative advantages in these product categories.

The RCA index for unskilled labor-intensive products has increased over time, indicating an overall improvement in the comparative advantage for this product category. However, although agricultural- and mineral resource-intensive products maintained their comparative advantage over the four periods, their competitiveness showed a downward trend, which is supported by the data in Appendix 2. The RCA estimates for Vietnam's human capital- and technology-intensive products were very low. Although this may be due to the low level of industrialization and insufficient access to technology, we should note that the RCA index for these commodity groups rose dramatically.

\section{Table 4}

RCA by Factor Intensity

\begin{tabular}{l|c|c|c|c}
\hline \multicolumn{1}{c|}{ Product groups } & $\mathbf{1 9 9 7 - 1 9 9 9}$ & $\mathbf{2 0 0 0 - 2 0 0 2}$ & $\mathbf{2 0 0 3 - 2 0 0 5}$ & $\mathbf{2 0 0 6 - 2 0 0 8}$ \\
\hline \hline Agricultural resource-intensive products & 2.78 & 2.94 & 2.43 & 2.13 \\
\hline Mineral resources-intensive products & 1.78 & 2.02 & 1.78 & 1.26 \\
\hline Unskilled labor-intensive products & 2.59 & 2.66 & 3.41 & 3.78 \\
\hline Human capital-intensive products & 0.26 & 0.36 & 0.46 & 0.59 \\
\hline Technology-intensive products & 0.12 & 0.16 & 0.18 & 0.25 \\
\hline
\end{tabular}

Source: The authors' computation based on UNSD data. 
Table 5 shows the top 30 product categories in terms of their RCA rankings for the periods 1997-1999 and 2006-2008. In terms of their factor intensity classification for the period 1997-1999, 16 were agricultural resource-intensive products; 4 were mineral resource-intensive products; 9 were unskilled labor-intensive products; and only 1 was a technology-intensive product. For the period 2006-2008, 18 were agricultural resourceintensive products, 4 were mineral resource-intensive products, 7 were unskilled laborintensive products, and there was only 1 human capital-intensive product.

As shown in Table 5, agricultural resource-intensive products accounted for more than half of the top 30 product categories. Although the number of agricultural resourceintensive product categories increased from 1997-1999 to 2006-2008, the share of these product categories in total exports declined over the same period. This indicates that Vietnam is becoming less specialized in these product categories. By contrast, the number of unskilled labor-intensive product categories declined from 9 in 1997-1999 to 7 in 2006-2008, but the share of these product categories in total exports remained unchanged, indicating a small increase in specialization in these product categories. 


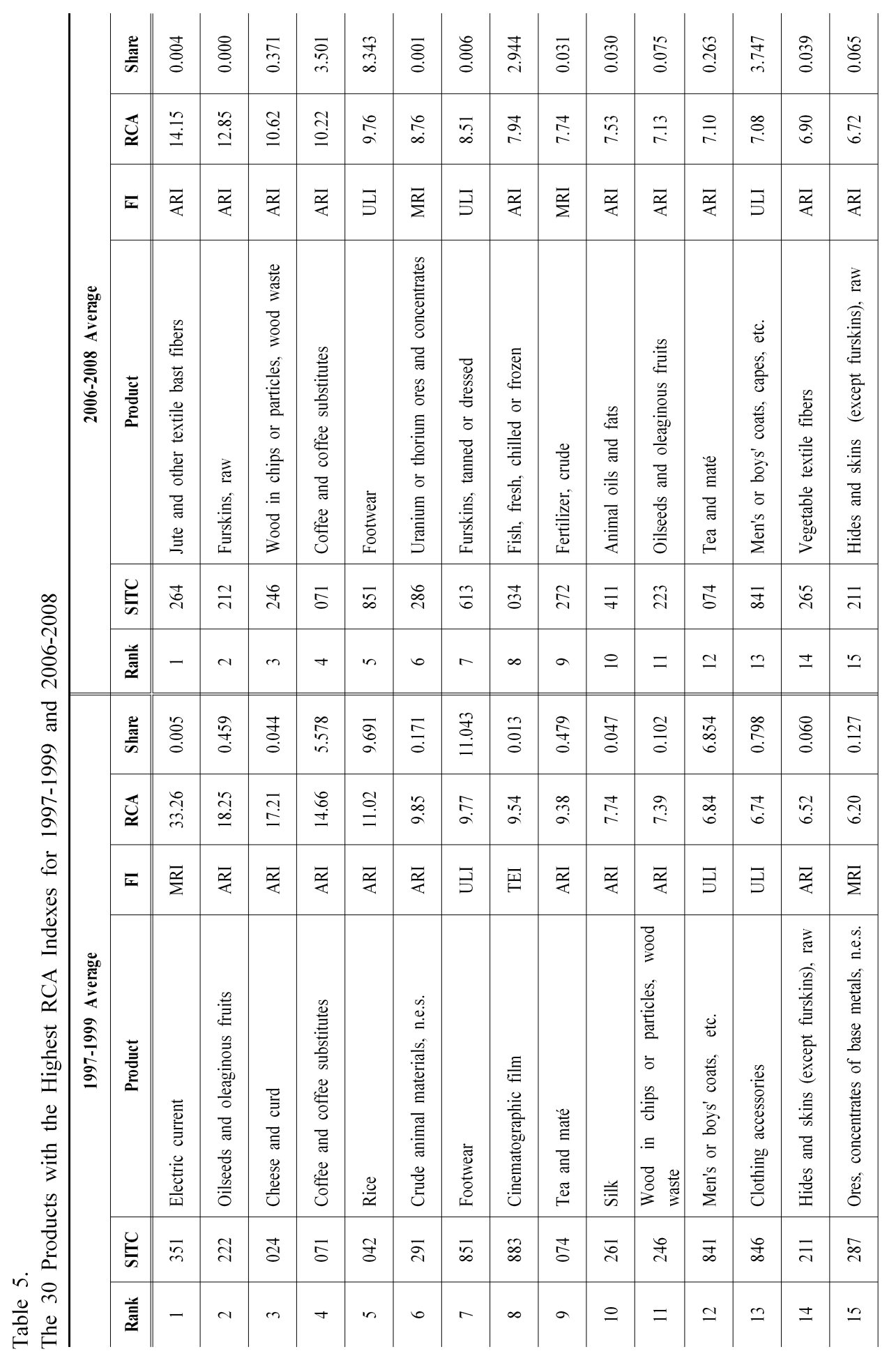




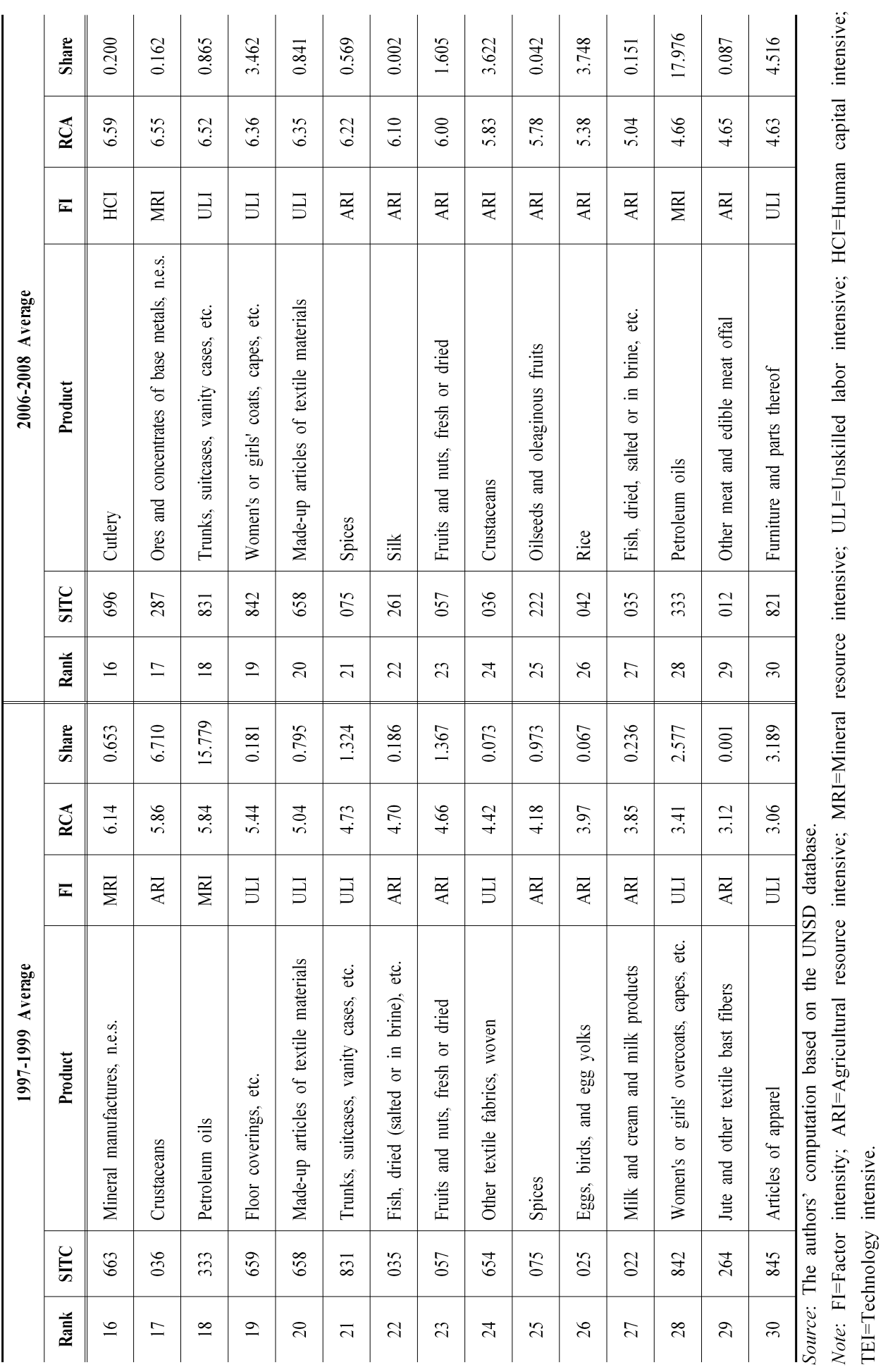


Table 6 presents the percentage of products with a comparative advantage according to the level of RCA for the periods 1997-1999 and 2006-2008. There was a shift toward higher RCA's from 1997-1999 to 2006-2008, indicating an increase in the diversity of Vietnam's exports. This is illustrated by the decrease in the share of products with a comparative disadvantage in all five product categories. In other words, the number of product categories in which Vietnam had a comparative advantage increased, indicating that Vietnam is beginning to rely on a wider range of exports.

Table 6.

Percentage of Products with a Competitive Advantage by RCA Level

\begin{tabular}{|c|c|c|c|c|c|}
\hline Product Categories & $4<\mathrm{RCA}$ & $\begin{array}{c}2<\text { RCA } \\
\leq 4\end{array}$ & $\begin{array}{c}1<\text { RCA } \\
\leq 2\end{array}$ & $\begin{array}{c}0<\mathrm{RCA} \\
\leq 1\end{array}$ & Total \\
\hline & \multicolumn{5}{|c|}{$(1997-1999)$} \\
\hline Agricultural resource-intensive products & 5.22 & 3.61 & 3.21 & 14.46 & 26.51 \\
\hline Mineral resource-intensive products & 1.61 & 0.80 & 1.20 & 11.24 & 14.86 \\
\hline Unskilled labor-intensive products & 2.81 & 1.61 & 1.61 & 8.43 & 14.46 \\
\hline Human capital-intensive products & 0.00 & 0.00 & 1.20 & 16.06 & 17.27 \\
\hline Technology-intensive products & 0.40 & 0.40 & 0.80 & 25.30 & 26.91 \\
\hline \multirow[t]{2}{*}{ Total } & 10.04 & 6.43 & 8.03 & 75.50 & 100.00 \\
\hline & \multicolumn{5}{|c|}{$(2006-2008)$} \\
\hline Agricultural resource-intensive products & 7.23 & 2.01 & 5.22 & 12.05 & 26.51 \\
\hline Mineral resource-intensive products & 1.61 & 1.61 & 2.01 & 9.64 & 14.86 \\
\hline Unskilled labor-intensive products & 3.61 & 3.61 & 3.61 & 3.61 & 14.46 \\
\hline Human capital-intensive products & 0.40 & 0.80 & 3.21 & 12.85 & 17.27 \\
\hline Technology-intensive products & 0.00 & 2.41 & 2.01 & 22.49 & 26.91 \\
\hline Total & 12.85 & 10.44 & 16.06 & 60.64 & 100.00 \\
\hline
\end{tabular}

Source: The authors' computation based on the UNSD database.

An analysis of the individual product categories indicates a dichotomy. For example, in terms of agricultural resource-intensive products, there was a shift toward weak or strong comparative advantages and a shift away from moderate comparative advantages. Unskilled labor- and human capital-intensive products made shifts towards weak, moderate, or high comparative advantages. This is consistent with the improvements made in the scope and quality of education in Vietnam in recent years. Mineral resources- and technology- intensive products shifted towards weak or moderate comparative advantages. 


\subsection{The Structural Stability of Vietnam's RCA}

\subsubsection{The Stability of the RCA Distribution}

Table 7 shows the stability of the RCA index, which was obtained by using the Galtonian regression method.7) We used this method to determine the extent to which Vietnam's export structure became specialized. As shown in Table7, the value of $\beta$ was less than unity, indicating that those commodity groups with a weak comparative advantage became more competitive, whereas those with a strong comparative advantage saw it decline. Thus, there was no substantial change in Vietnam's overall trade patterns from 1997-1999 to 2006-2008. The $\beta / \mathrm{R}$ ratios suggest a convergence of the commodity groups' comparative advantages and indicate a stable dispersion in the RCA distribution.

\section{Table 7.}

Galtonian Regression Results

\begin{tabular}{c|c|c|c|c|c|c}
\hline$R C A_{i j}^{t 1}$ & $R C A_{i j}^{t 2}$ & Constant & $\beta$ & $\mathrm{t}$-test & $\mathrm{R}$ & $\beta / \mathrm{R}$ \\
\hline \hline $1997-1999$ & $2000-2002$ & 0.55 & $0.65^{* *}$ & $(17.82)$ & 0.75 & 0.87 \\
\hline $2000-2002$ & $2003-2005$ & 0.58 & $0.54^{* *}$ & $(15.68)$ & 0.71 & 0.76 \\
\hline $2003-2005$ & $2006-2008$ & 0.51 & $0.80^{* *}$ & $(16.84)$ & 0.73 & 1.09 \\
\hline $1997-1999$ & $2006-2009$ & 1.23 & $0.27^{* *}$ & $(6.28)$ & 0.37 & 0.73 \\
\hline
\end{tabular}

Source: The authors' computation.

Note: ${ }^{*}$ and $* *$ denote significance at the 0.05 and 0.01 levels, respectively.

\subsubsection{The Intra-Distribution Dynamics}

We examined the dynamics of the RCA index by analyzing the transition probability matrix ${ }^{8)}$. Table 8 presents the estimated transition probability matrix between the starting period (1997-1999) and the ending period (2006-2008). The initial and final distributions indicate an improvement in the RCA index for Vietnam. Specifically, the percentage of product categories with a comparative disadvantage was $75 \%$ for 1997-1999. However, this declined to more than $60.6 \%$ for $2006-2008$.

7) Appendix 4 provides the Galtonian regression results for each period.

8) Appendices 5A, 5B, and 5C provide the transition probability matrices for 1997-1999 and 2000-2002, 2000-2002 and 2003-2005, and 2003-2005 and 2006-2008, respectively. 
Table 8.

Transition Probability Matrix for (1997-1999 and 2006-2008)

\begin{tabular}{c|c|c|c|c|c}
\hline & \multicolumn{5}{|c}{ Period 2006-2008 } \\
\cline { 2 - 6 } & RCA & a & b & c & d \\
\cline { 2 - 6 } & $\mathrm{a}$ & 0.713 & 0.165 & 0.085 & 0.037 \\
\cline { 2 - 6 } Period & $\mathrm{b}$ & 0.350 & 0.400 & 0.150 & 0.100 \\
\cline { 2 - 6 } $\mathbf{1 9 9 7 -}$ & $\mathrm{c}$ & 0.375 & 0.063 & 0.188 & 0.375 \\
\cline { 2 - 6 } $\mathbf{1 9 9 9}$ & $\mathrm{d}$ & 0.160 & 0.000 & 0.160 & 0.680 \\
\cline { 2 - 6 } & $\begin{array}{c}\text { Initial } \\
\text { distribution }\end{array}$ & 0.755 & 0.080 & 0.064 & 0.100 \\
\cline { 2 - 6 } & $\begin{array}{c}\text { Final } \\
\text { distribution }\end{array}$ & 0.606 & 0.161 & 0.104 & 0.129 \\
\hline
\end{tabular}

Source: The authors' computation based on the UNSD at the three-digit SITC level.

An in-depth analysis of the transition probability matrix suggests several important characteristics. First, there was little change in the RCA index values from 1997-1999 to 2006-2008 for the product categories belonging to Class a (comparative disadvantage) or Class $d$ (high comparative advantage). For example, the value of the diagonal element was 0.713 for Class a, implying that the probability of a product with a comparative disadvantage in the period 1997-1999 maintains the same status as in the period 2006-2008 with a diagonal element of 0.713 . The probabilities of moving from Class a to Class $b$ (weak comparative advantage) and Class $\mathrm{c}$ (moderate comparative advantage) were 0.165 and 0.085 , respectively. The probability of a product category moving from Class a to Class $\mathrm{d}$ (high comparative advantage) was very low. The RCA index for Class $d$ also showed a similar pattern. According to the diagonal element, the probability of a product with a high comparative advantage in the period 1997-1999 maintaining that advantage (i.e., remaining in Class d) was 0.680 . The probability of a product category moving from Class $d$ to Class $\mathrm{a}$, or $\mathrm{c}$ was also low, and that of a product category moving from Class $\mathrm{d}$ to Class $\mathrm{b}$ was zero.

Secondly, unlike the product categories belonging to Class a or Class d, those belonging to Class $\mathrm{b}$ (weak comparative advantage) or Class $\mathrm{c}$ (moderate comparative advantage) showed substantial variations in their patterns. In terms of Class $b$, the probability of a product category losing its comparative advantage was relatively high (0.350). Furthermore, the probability of a product category moving from Class $b$ to Class $c$ or $\mathrm{d}$ was low. The probability of a product category which belongs to Class $\mathrm{c}$ remaining in that class during period 2006-2008 was only 0.188 . However, the probability of a product category moving from Class $\mathrm{c}$ to Class a, or Class $\mathrm{d}$ was relatively high (0.375), whereas that of a product category moving from Class $\mathrm{c}$ to Class $\mathrm{b}$ was low. 
Table 9.

The Mobility Index for the Period 1997-2008

\begin{tabular}{c|c|c|c}
\hline From & To & $\mathbf{M}_{\mathbf{1}}$ & $\mathbf{M}_{\mathbf{2}}$ \\
\hline \hline $1997-1999$ & $2000-2002$ & 0.446 & 0.880 \\
\hline $2000-2002$ & $2003-2005$ & 0.495 & 0.940 \\
\hline $2003-2005$ & $2006-2008$ & 0.425 & 0.867 \\
\hline $1997-2000$ & $2006-2008$ & 0.673 & 0.989 \\
\hline
\end{tabular}

Source: The authors' computation.

The $M_{1}$ values indicate a low degree of mobility from 1997-1999 to 2000-2002, from 2000-2002 to 2003-2005, and from 2003-2005 to 2006-2008. However, the degree of mobility from 1997-1999 to 2006-2008 was moderate as a result of the mobility of the product categories in Classes $b$ and $c$. In terms of mobility ranking between periods, both indices provided the same results: the most dynamic period was from 2000-2002 to 2003-2005, whereas the most static period was from 2003-2005 to 2006-2008.

\subsection{The Degree of Commodity Concentration}

Table 10 displays a breakdown of the Gini-Hirschman index into the same five commodity groups by factor intensity for the period 1997-2008: agricultural resourceintensive products (ARI), mineral resource-intensive products (MRI), unskilled laborintensive products (ULI), human capital-intensive products (HCI), and technology intensiveproducts (TEI).

As shown in Table 10, mineral resource-intensive products showed the highest degree of specialization, indicating that exports of these products involved only a narrow range of products. In fact, petroleum oils and oils from bituminous minerals (SITC 333) accounted for more than $80 \%$ of the total mineral resource-intensive exports. By contrast, human capital-intensive products showed the lowest degree of specialization, indicating that exports of these products involved a wide range of products. The leading product category (SITC 785 - Motorcycles) accounted for only approximately $18 \%$ of the total human capital -intensive exports. 
Table 10.

The Gini-Hirschman Index

\begin{tabular}{c|c|c|c|c|c}
\hline Year & ARI & MRI & ULI & HCI & TEI \\
\hline \hline 1997 & 0.39 & 0.84 & 0.42 & 0.25 & 0.47 \\
\hline 1998 & 0.45 & 0.80 & 0.43 & 0.29 & 0.53 \\
\hline 1999 & 0.42 & 0.84 & 0.42 & 0.26 & 0.44 \\
\hline 2000 & 0.40 & 0.88 & 0.42 & 0.28 & 0.43 \\
\hline 2001 & 0.39 & 0.85 & 0.41 & 0.30 & 0.39 \\
\hline 2002 & 0.39 & 0.87 & 0.39 & 0.26 & 0.33 \\
\hline 2003 & 0.39 & 0.86 & 0.38 & 0.26 & 0.30 \\
\hline 2004 & 0.36 & 0.86 & 0.37 & 0.27 & 0.30 \\
\hline 2005 & 0.35 & 0.84 & 0.36 & 0.23 & 0.30 \\
\hline 2006 & 0.33 & 0.82 & 0.36 & 0.23 & 0.29 \\
\hline 2007 & 0.33 & 0.79 & 0.34 & 0.23 & 0.30 \\
\hline 2008 & 0.34 & 0.77 & 0.33 & 0.24 & 0.28 \\
\hline$\beta$ & $0.01^{* *}$ & 0.00 & $-0.01^{* *}$ & $0.01^{* *}$ & $-0.02^{* *}$ \\
\hline t-test & $(-6.19)$ & $(-1.58)$ & $(-13.61)$ & $(-2.71)$ & $(-7.90)$ \\
\hline Adj $\mathrm{R}^{2}$ & 0.77 & 0.12 & 0.94 & 0.36 & 0.85 \\
\hline
\end{tabular}

Source: The authors' computation based on UNSD data.

Note: $*$ and $* *$ indicate significance a t 0.05 and 0.01 levels, respectively.

Following Ferto (2007), we conducted a regression analysis in which the log of the $\mathrm{GH}$ index was regressed on a simple time trend. The results indicated an ambiguous downward trend in the degree of specialization for mineral resources-intensive products and a sharply declining trend in the specialization of exports for all other commodity groups.

\section{Conclusion}

This paper employs various analytical tools to investigate the patterns and dynamics of Vietnam's comparative advantage for the period 1997-2008. The key findings are summarized as follows: Firstly, the Galtonian regression results indicate a convergence of Vietnam's comparative advantages. Commodity groups with a weak comparative advantage became more competitive, whereas those with a strong comparative advantage became less competitive. Secondly, interms of intra-distribution dynamics, the results indicate a relatively high degree of persistence for commodity groups with no initial comparative advantage(Class $a$ ) and those with a high initial comparative advantage(Class $d$ ), 
implying a low degree of mobility in the trade pattern for Classes a and $d$. Thirdly, mineral resource-intensive products showed a high degree of export specialization, whereas the other product categories showed a high degree of export diversification. Overall, these results indicate a downward trend in the degree of specialization for all commodity groups. Fourthly, although the results provide evidence that human capital-and technologyintensive products have become more competitive, they are still nowhere close to having a strong comparative advantage. Finally, Vietnam's exports were dominated by unskilled labor-and agricultural resource-intensive products. However, there was a discernable reduction in the traditional dominance of exports by the agricultural sector. Unskilled labor-intensive products became more competitive, whereas agricultural resources- and mineral resource-intensive products became less competitive.

From a policy point of view, Vietnam still depends heavily on agricultural resourcesand unskilled labor-intensive exports. A high degree of specialization implies the concentration of resources in these sectors. However, this may be dangerous in the case where there is an asymmetric shock to the Vietnamese economy. Therefore, Vietnam should further expand its export base, which can be an important source of comparative advantage for all product categories, not just for the agricultural resources- and unskilled labor-intensive product categories. In this case, Vietnam should further promote the diversification of its economy toward human capital-intensive products in order to better compete with other countries in its region. Although Vietnam already has a strong labor force, it should continue to make improvements in this area. Hence, Vietnam should focus on fostering a highly educated population by implementing policies which target increased education, an indispensible component for any country aiming to improve its competitiveness.

In addition to improving the competitiveness of human capital-intensive products, Vietnam should take appropriate measures to enhance its comparative advantage in the area of technology-intensive products. For this, it should further liberalize its trade regime, which should provide more opportunities for accessing foreign technology. Furthermore, it is necessary to promote research and development activities. Innovation is a key element in any effort toward sustainable economic development. Therefore, Vietnam should implement policies which will better foster innovation, and help the country make a shift towards technology-intensive exports.

Vietnam's success in deriving benefits from its participation in the world economy greatly depends on its ability to foster human capital formation, facilitate technological transfer, and create a culture based on innovation. Making these changes in an effective and timely manner should allow Vietnam to expand its human capital- and technology-intensive exports while continuing to progress as a justifiable competitor in the global trade industry. 


\section{Appendices}

\section{Appendix 1: Measurement of Revealed Comparative Advantage}

Revealed comparative advantage (RCA) was conceived by Blassa (1965), modified by Bowen (1983, 1985, 1986), and subsequently employed in a number of empirical studies for analyzing a country's comparative advantage in various sectors (Balassa \& Bauwens, 1987; Son \& Wilson, 1995; Kalirajan \& Shand, 1998). This index pertains to the relative trade performance of individual countries in particular commodities (Balassa, 1965, 1977, 1986). Balassa (1965) suggested that comparative advantage can be "revealed" by observed trade patterns reflecting differences in factor endow-ments across countries. Simply put, the revealed comparative advantage of country $j$ in the export of product $i$ is measured by the ratio of the share of commodity $i$ in the country's exports to the share of that commodity in the reference group's exports. RCA is calculated as follows:

$$
R C A_{i j}=\frac{X_{i j} / \sum X_{j}}{X_{i n} / \sum X_{n}} \quad\left(0 \leq R C A_{i j}<\infty\right),
$$

where

$R C A_{i j}$ is the revealed comparative advantage of country $j$ in commodity $i$;

$X_{i j} \quad$ refers to exports of commodity $i$ by country $j$;

$\sum X_{j} \quad$ refers to total exports by country $j$;

$X_{i n} \quad$ refers to exports of commodity $i$ by the reference group;

$\sum X_{n}$ refers to total exports by the reference group.

This index ranges from zero to infinity. If the value of the index is greater than unity, then the country has an RCA in commodity $i$. This can occur when the share of that commodity in the country's exports exceeds its share in the reference group's exports. The factors that contribute to RCA movements are mainly economic, such as structural changes, improved world demand, and trade specialization. Similarly, if the value of the index is less than unity, then the country is said to have a revealed comparative disadvantage. 


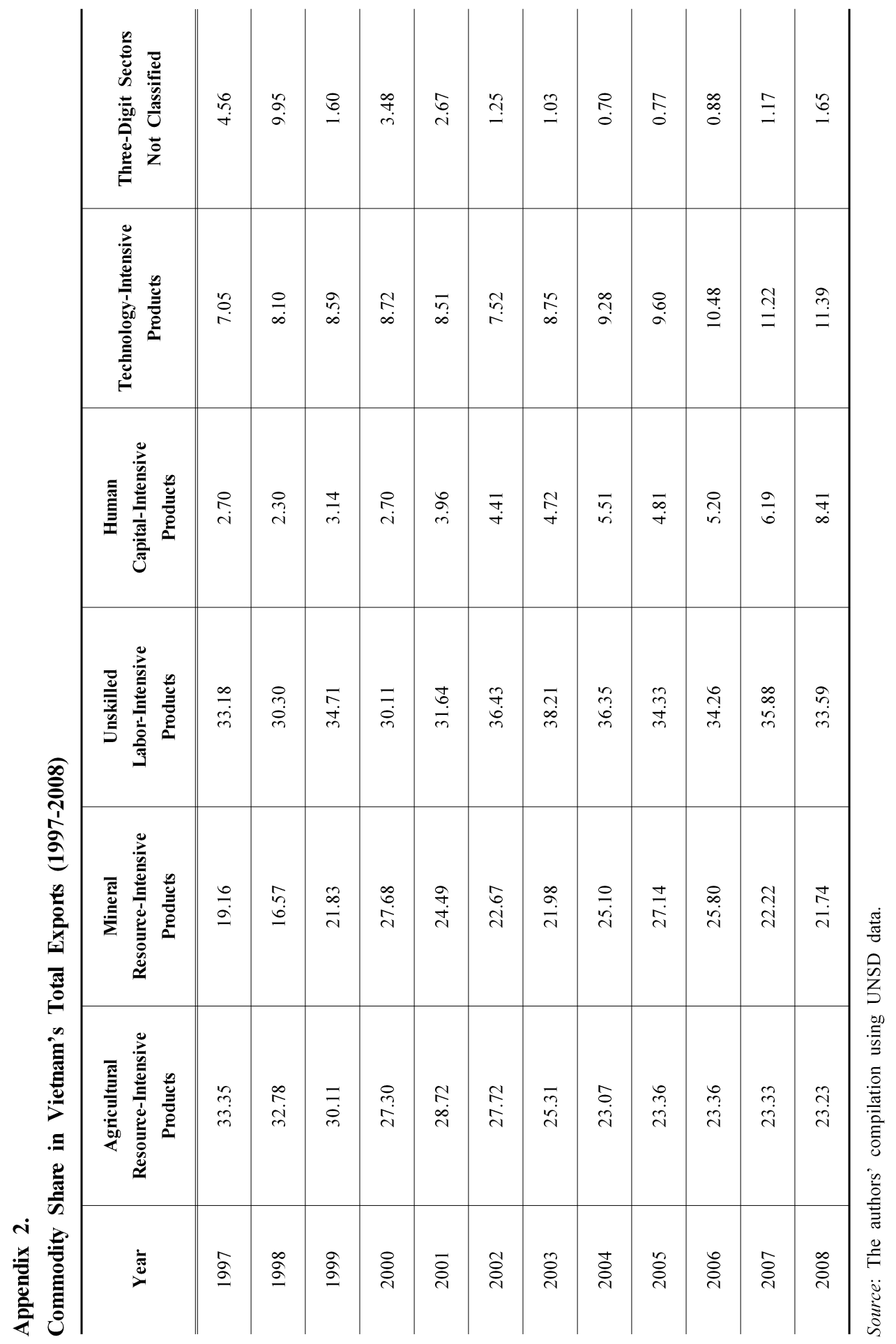




\section{Appendix 3.}

Frequency Distribution of Vietnam's RCA by Factor Intensity

\begin{tabular}{|c|c|c|c|c|}
\hline RCA range & 1997-1999 & 2000-2002 & 2003-2005 & 2006-2008 \\
\hline $0<\mathrm{RCA} \leq \mathrm{I}$ & 75.50 & 70.28 & 64.66 & 60.64 \\
\hline $1<\mathrm{RCA} \leq 2$ & 8.03 & 12.85 & 14.86 & 16.06 \\
\hline $2<\mathrm{RCA} \leq 4$ & 6.43 & 5.62 & 10.84 & 10.44 \\
\hline $4<\mathrm{RCA}$ & 10.04 & 11.24 & 9.64 & 12.85 \\
\hline Mean RCA & 1.38 & 1.45 & 1.36 & 1.60 \\
\hline Maximum & 33.26 & 19.92 & 11.82 & 14.15 \\
\hline \multirow[t]{2}{*}{ Standard deviation } & 3.31 & 2.29 & 2.21 & 2.42 \\
\hline & \multicolumn{4}{|c|}{ (Agricultural resource-intensive products) } \\
\hline $0<\mathrm{RCA} \leq \mathrm{I}$ & 54.55 & 51.52 & 43.94 & 45.45 \\
\hline $1<\mathrm{RCA} \leq 2$ & 12.12 & 15.15 & 18.18 & 19.70 \\
\hline $2<\mathrm{RCA} \leq 4$ & 13.64 & 9.09 & 16.67 & 7.58 \\
\hline $4<\mathrm{RCA}$ & 19.70 & 24.24 & 21.21 & 27.27 \\
\hline Mean RCA & 2.54 & 2.55 & 2.38 & 2.68 \\
\hline Maximum & 18.25 & 17.94 & 10.82 & 14.15 \\
\hline \multirow[t]{2}{*}{ Standard deviation } & 4.07 & 3.53 & 2.93 & 3.38 \\
\hline & \multicolumn{4}{|c|}{ (Mineral resource-intensive products) } \\
\hline $0<\mathrm{RCA} \leq 1$ & 75.68 & 75.68 & 75.68 & 64.86 \\
\hline $1<\mathrm{RCA} \leq 2$ & 8.11 & 13.51 & 8.11 & 13.51 \\
\hline $2<\mathrm{RCA} \leq 4$ & 5.41 & 0.00 & 8.11 & 10.81 \\
\hline $4<\mathrm{RCA}$ & 10.81 & 10.81 & 8.11 & 10.81 \\
\hline Mean RCA & 1.73 & 1.35 & 1.06 & 1.34 \\
\hline Maximum & 33.26 & 19.92 & 11.82 & 8.76 \\
\hline \multirow[t]{2}{*}{ Standard deviation } & 5.59 & 3.54 & 2.29 & 2.20 \\
\hline & \multicolumn{4}{|c|}{ (Unskilled labor-intensive products) } \\
\hline $0<\mathrm{RCA} \leq \mathrm{I}$ & 58.33 & 38.89 & 30.56 & 25.00 \\
\hline $1<\mathrm{RCA} \leq 2$ & 11.11 & 27.78 & 30.56 & 25.00 \\
\hline $2<\mathrm{RCA} \leq 4$ & 11.11 & 13.89 & 16.67 & 25.00 \\
\hline $4<\mathrm{RCA}$ & 19.44 & 19.44 & 16.67 & 25.00 \\
\hline Mean RCA & 1.95 & 2.54 & 2.37 & 2.81 \\
\hline Maximum & 9.77 & 19.29 & 10.90 & 9.76 \\
\hline Standard deviation & 2.36 & 3.74 & 2.42 & 2.43 \\
\hline
\end{tabular}




\begin{tabular}{l|c|c|c|c|c}
\hline \multicolumn{1}{c|}{ RCA range } & $\mathbf{1 9 9 7 - 1 9 9 9}$ & $\mathbf{2 0 0 0 - 2 0 0 2}$ & $\mathbf{2 0 0 3 - 2 0 0 5}$ & $\mathbf{2 0 0 6 - 2 0 0 8}$ \\
\hline \hline & \multicolumn{4}{c}{ (Human capital-intensive products) } \\
\hline $0<\mathrm{RCA} \leq \mathrm{I}$ & 93.02 & 83.72 & 79.07 & 74.42 \\
\hline $1<\mathrm{RCA} \leq 2$ & 6.98 & 9.30 & 11.63 & 18.60 \\
\hline $2<\mathrm{RCA} \leq 4$ & 0.00 & 4.65 & 6.98 & 4.65 \\
\hline $4<\mathrm{RCA}$ & 0.00 & 2.33 & 2.33 & 2.33 \\
\hline Mean RCA & 0.34 & 0.66 & 0.69 & 0.83 \\
\hline Maximum & 1.81 & 8.12 & 5.86 & 6.59 \\
\hline Standard deviation & 0.40 & 1.29 & 1.04 & 1.17 \\
\hline & & Technology-intensive products) & \\
\hline $0<$ RCA $\leq$ I & 94.03 & 92.54 & 88.06 & 83.58 \\
\hline $1<$ RCA $\leq 2$ & 2.99 & 5.97 & 8.96 & 7.46 \\
\hline $2<$ RCA $\leq 4$ & 1.49 & 0.00 & 2.99 & 8.96 \\
\hline $4<$ RCA & 1.49 & 1.49 & 0.00 & 0.00 \\
\hline Mean RCA & 0.41 & 0.34 & 0.41 & 0.53 \\
\hline Maximum & 9.54 & 2.05 & 2.66 & 2.89 \\
\hline Standard deviation & 1.21 & 0.43 & 0.59 & 0.75 \\
\hline
\end{tabular}

Source: The authors' computation using UNSD data.

\section{Appendix 4}

Galtonian Regression Results

\begin{tabular}{c|c|c|c|c|c|c}
\hline$R C A_{i j}^{t 1}$ & $R C A_{i j}^{t 2}$ & Constant & $\beta$ & t-test & $\mathbf{R}$ & $\beta / \mathbf{R}$ \\
\hline \hline 1997 & 1998 & -0.01 & $0.77^{* *}$ & $(27.74)$ & 0.87 & $\mathrm{c} 0.88$ \\
\hline 1998 & 1999 & 0.60 & $0.85^{* *}$ & $(9.06)$ & 0.50 & 1.71 \\
\hline 1999 & 2000 & 0.79 & $0.37^{* *}$ & $(8.73)$ & 0.49 & 0.75 \\
\hline 2000 & 2001 & 0.64 & $0.61^{* *}$ & $(13.46)$ & 0.65 & 0.94 \\
\hline 2001 & 2002 & 0.33 & $0.73^{* *}$ & $(24.43)$ & 0.84 & 0.87 \\
\hline 2002 & 2003 & 0.41 & $0.73^{* *}$ & $(19.81)$ & 0.78 & 0.93 \\
\hline 2003 & 2004 & 0.20 & $0.79^{* *}$ & $(30.98)$ & 0.89 & 0.88 \\
\hline 2004 & 2005 & 0.17 & $0.94^{* *}$ & $(28.96)$ & 0.88 & 1.07 \\
\hline 2005 & 2006 & 0.26 & $0.95^{* *}$ & $(23.73)$ & 0.83 & 1.14 \\
\hline 2006 & 2007 & 0.35 & $0.76^{* *}$ & $(22.55)$ & 0.82 & 0.92 \\
\hline 2007 & 2008 & 0.29 & $0.77^{* *}$ & $(22.26)$ & 0.82 & 0.94 \\
\hline 1997 & 2008 & 0.90 & $0.44^{* *}$ & $(10.11)$ & 0.54 & 0.82 \\
\hline
\end{tabular}

Source: The authors' computation.

Note: * and *denote significance at the 0.05 and 0.01 levels, respectively. 


\section{Appendix 5A.}

Transition Probability Matrix (1997-1999 and 2000-2002)

\begin{tabular}{|c|c|c|c|c|c|}
\hline \multirow{8}{*}{$\begin{array}{c}\text { Period } \\
1997- \\
1999\end{array}$} & \multicolumn{5}{|c|}{ Period 2000-2002 } \\
\hline & RCA & $\mathbf{a}$ & b & c & d \\
\hline & $\mathbf{a}$ & 0.888 & 0.074 & 0.016 & 0.021 \\
\hline & b & 0.200 & 0.600 & 0.100 & 0.050 \\
\hline & c & 0.063 & 0.375 & 0.375 & 0.188 \\
\hline & d & 0.080 & 0.000 & 0.120 & 0.800 \\
\hline & Initial distribution & 0.755 & 0.080 & 0.064 & 0.100 \\
\hline & Final distribution & 0.703 & 0.129 & 0.056 & 0.112 \\
\hline
\end{tabular}

Source: The authors' computation based on UNSD data at the three-digit SITC level.

\section{Appendix 5B.}

Transition Probability Matrix (2000-2002 and 2003-2005)

\begin{tabular}{|c|c|c|c|c|c|}
\hline \multirow{8}{*}{$\begin{array}{c}\text { Period } \\
2000- \\
2002\end{array}$} & \multicolumn{5}{|c|}{ Period 2003-2005 } \\
\hline & RCA & $\mathbf{a}$ & b & c & d \\
\hline & $\mathbf{a}$ & 0.863 & 0.109 & 0.029 & 0.000 \\
\hline & b & 0.219 & 0.438 & 0.313 & 0.031 \\
\hline & c & 0.000 & 0.286 & 0.500 & 0.214 \\
\hline & d & 0.107 & 0.000 & 0.179 & 0.714 \\
\hline & Initial distribution & 0.703 & 0.129 & 0.056 & 0.112 \\
\hline & Final distribution & 0.647 & 0.149 & 0.108 & 0.096 \\
\hline
\end{tabular}

Source: The authors' computation based on UNSD data at the three-digit SITC level.

\section{Appendix 5C.}

Transition Probability Matrix (2003-2005 and 2006-2008)

\begin{tabular}{|c|c|c|c|c|c|}
\hline \multirow{8}{*}{$\begin{array}{c}\text { Period } \\
2003- \\
2005\end{array}$} & \multicolumn{5}{|c|}{ Period 2006-2008 } \\
\hline & RCA & $\mathbf{a}$ & b & c & d \\
\hline & $\mathbf{a}$ & 0.851 & 0.099 & 0.031 & 0.019 \\
\hline & b & 0.270 & 0.514 & 0.216 & 0.000 \\
\hline & c & 0.111 & 0.185 & 0.444 & 0.259 \\
\hline & d & 0.042 & 0.000 & 0.042 & 0.917 \\
\hline & Initial distribution & 0.647 & 0.149 & 0.108 & 0.096 \\
\hline & Final distribution & 0.606 & 0.161 & 0.104 & 0.129 \\
\hline
\end{tabular}

Source: The authors' computation based on UNSD data at the three-digit SITC level. 


\section{REFERENCES}

Amador, J., Cabral, S., and Maria, J. R. (2007). 'Relative Export Structures and Vertical Specialization: a Simple Cross-country Index,' Banco de Portugal Working Paper 2007-1, Lisbon.

Balassa, B. (1965). 'Trade Liberalization and Revealed Comparative Advantage,' The Manchester School of Economic and Social Studies 33: 99-124.

Balassa, B. (1977). 'Revealed' Comparative Advantage Revisited: An Analysis of Relative Export Shares of the Industrial Countries, 1953-1971,' The Manchester School of Economic and Social Studies 45: 327-44.

Balassa, B. (1986). 'Comparative Advantage in Manufactured Goods: A Reappraisal,' The Review of Economics and Statistics 68: 315-319.

Balassa, B. and Bauwens, L. (1987). Intra-industry Specialization in a Multi-Country and Multi-Industry Framework. The Economic Journal 97: 923-939.

Bojnec, S. and Ferto, I. (2008). 'European Enlargement and Agro-Food Trade,' Canadian Journal of Agricultural Economics 56: 563-579.

Bowen, H. P. (1983). 'On the Theoretical Interpretation of Indices of Trade Intensity and Revealed Comparative Advantage,' Weltwirtschaftliches Archiv 199: 464-472.

Bowen, H. P. (1985). 'On Measuring Comparative Advantage: A Reply and Extension,' Weltwirtschaftliches Archiv 121: 464-472.

Bowen, H. P. (1986). 'On Measuring Comparative Advantage: Further Comments,' Weltwirtschaftliches Archiv 199: 379-381.

Brasili, A., Epifani, P. and Helg, R. (2000). 'On the Dynamics of Trade Patterns,' De economist 148: 233-257.

Cantwell, J. (1989). Technological Innovation and Multinational Corporations, Oxford: Blackwell.

Dalum, B., Laursen, K. and Villumsen, G. (1998). 'Structural Change in OECD Export Specialization Patterns: De-specialization and 'Stickiness,' International Review of Applied Economics, 12: 423-443.

Ferto, I. (2007). 'The Dynamics of Trade in Central and Eastern European Countries,' Managing Global Transitions 5: 5-23.

Grigorovici, C. (2009). 'Analyzing the Degree of Specialization in Romania's Services Trade,' Romanian Journal of Economic Forecasting 10: 95-115.

Hillman, A. L. (1980). 'Observation on the Relation between Revealed Comparative Advantage and Comparative Advantage as Indicated by Pre-Trade Relative Prices,' Weltwirtschaftliches Archiv 116: 315-321. 
Hinloopen, J. and Van Marrewijk, C. (2001). 'On the Empirical Distribution of the Balassa Index,' Weltwirtschaftliches Archiv 137: 1-35.

Kalirajan, K. P. and Shand, R. T. (1998). Trade Flows between Australia, India and South Africa: A Growth Triangle?. Economic Papers 17: 89-96.

Krause, B. (1982). The United States Economic Policy Toward the Association of Southeast Asian Nations: Meeting the Japanese Challenges, The Brookings Institution: Washington, D.C.: USA.

Laursen, K. (1998). 'Revealed Comparative Advantage and Alternative Measures of International Specialization,' Danish Research Unit for Industrial Dynamics Working Paper 98-30, Copenhagen.

Proudman, J. and Redding, S. (2000). 'Evolving Patterns of International Trade,' Review of International Economics 8: 373-396.

Quah, D. (1996). 'Aggregate and Regional Disaggregate Fluctuations,' Empirical Economics 21: 137-159.

Shorrocks, A. (1978). 'The measurement of Mobility,' Econometrica 46: 1013-1024.

Son, I. and Wilson, K. (1995). 'Australia-Korea Trade: Recent Structure and Future Prospects,' Economic Papers 14: 83-96.

Vollrath, T. L. (1991). 'A Theoretical Evaluation of Alternative Trade Intensity Measures of Revealed Comparative Advantage,' Weltwirtschaftliches Archiv 127: 265-280. 